\title{
Preparation and nutritional evaluation of wastelage using poultry droppings and napier grass
}

\author{
Panna MSJ, SMA Islam, AKMA Kabir and MRI Khan*
}

Department of Animal Science, Bangladesh Agricultural University, Mymensingh-2202.

\begin{abstract}
An experiment was conducted with Napier grass (NG) treated with Poultry droppings (PD) and rice straw and ensiled with molasses to increase the nutritional and preservation quality of Napier grass. Chopped Napier grass was preserved in plastic containers under airtight condition at room temperature based on the treatments T0 (0\% PD), T1 (15\% PD), T2 (30\% PD) and T3 (45\% PD) with 5\% molasses and $20 \%$ rice straw as fresh basis in each treatment to investigate physical quality, chemical composition, in vitro organic matter digestibility (IVOMD) and metabolizable energy (ME) content at 0, 30, 45, 60 and 75 days. The physical quality (color, smell, and hardness) of Napier grass mixer were improved in Poultry droppings added treatments till 75 days of ensiling. The $\mathrm{pH}$ value was decreased $(P<0.05)$ with the increasing of PD and ensiling time. The dry matter (DM), crude protein $(C P)$ and ash were increased $(P<0.05)$ and crude fiber (CF) was decreased $(P<0.05)$ in all the treatments $(\mathrm{T} 1, \mathrm{~T} 2$ and T3) compared to control one T0. The $\mathrm{CP}, \mathrm{DM}$ and ash were increased $(P<0.05)$ and $\mathrm{CF}$ and $\mathrm{EE}$ were decreased $(P<0.05)$ after ensiling. The EE content was not signified $(P>0.05)$ between T1 and T2. The CF content was decreased $(P<0.05)$ with the increase of Poultry droppings and ensiling time. The organic matter digestibility (OMD) and metabolizable energy $(\mathrm{ME})$ content were increased $(P<0.05)$ with the PD level and ensiling time. Considering all the physical and chemical properties, among all the treatments, $30 \%$ and $45 \%$ PD are acceptable for preparing wastelage. Thus cost effective and environment friendly feed can be prepared.
\end{abstract}

Key words: napier grass, poultry droppings, ensiling, wastelage, nutritive value

\section{Introduction}

Poultry population in Bangladesh is estimated about 304.17 million where chicken population is about 255.31 million and Duck population is about 48.86 (DLS, 2016). Livestock is an important component of the economy of Bangladesh which contributes about $1.66 \%$ to GDP and $14.21 \%$ to Agricultural sector (Bangladesh Economic Survey, 2015). A large number of animals are suffering from shortage of feeds both in quality and quantity. The available roughage and concentrate for feeding livestock can meet only 50 and $10 \%$, respectively of the requirement in Bangladesh (Haque et al., 2007). The livestock is beset with innumerable problems such as inadequate feed supply, under nourishment, high incidence of diseases, improper management in one side and poor genetic makeup on the other side. Successful animal production requires year-round animal feed, using appropriate technology which should be properly planned, keeping in view of the pressing demand of cereals and other needs of human being.

Because of scarcity of land for human food production it is difficult to spare more land exclusively for the production of livestock feed. Commercial poultry industry is growing rapidly in Bangladesh and annual growth rate of chicken population is 5.3 percent (GOB, 2010). In Bangladesh total livestock production is 3931.37 lakh and total poultry production is 3379.98 lakh (DLS, 2018). Due to lack of proper disposal system, a large amount of poultry droppings are creating environmental problems (soil, air, water pollution) which ultimately cause the health hazards for human. Poultry waste can be rendered free of pathogens by ensiling (Hadjipanayiotou 1984; Daniels et al., 1983) and deep stacking (Strickler, 1977). As poultry droppings contain higher level of feed nutrients specially CP (crude protein). Preparation of wastelage with poultry droppings enhance the

*Corresponding author: rikhanbau@yahoo.com 
Panna et al. (2019) Bang. J. Anim. Sci. 48 (1):48-56

nutritive value of Napier grass and also reduce the environment pollution.

The major constraint that influences the productivity of livestock is the shortage of feed both in quantity and quality. The major feed resources for livestock come from natural pasture and crop residue. However, they are poor in quality and provide inadequate protein, energy, vitamins and minerals. Nevertheless, the feed supply to animals can be improved by cultivation of tropically adapted forage species, which give reasonable yield under drought and unstable climatic conditions. One of such forages is the Napier grass (Pennisetum purpureum).

Napier grass is an important fodder in Bangladesh and has been increasingly associated with intensive (stall-feeding/zero grazing) and semi-intensive dairy cattle and goat production systems to meet the increasing demand for milk and meat. It is one of the most promising grasses available for ruminant production in tropical areas because of its high potential dry matter (DM) yield. But a major problem of it is left as residual by animals due to hardness of steams.

Wastelage is the products produced by collecting fresh waste e.g. poultry droppings, biogas slurry, cow dung etc. from farm, mixing it with forage, hay, straw or other crop residues and ensiling the mixture under anaerobic condition. These ensiled mixtures may be utilized as an important source of protein and energy in the diet of ruminants. Addition of molasses and ensiling of crop residues rice straw can be the effective means of improving the nutritive value and keeping quality. It is suitable for feeding ruminants as it is wholesome, effective, palatable, dust free and promotes fermentation. It helps in facilitating the natural preservation by lowering the $\mathrm{pH}$ and producing lactic acid bacteria (Premiar, 2006). It increases the palatability and also digestibility of rice straw (Sarker et al., 2018).

Ensiling of chopping Napier grass along with poultry droppings and molasses may produce a good quality wastelage for feeding cattle having desire palatability, nutrient content and digestibility. So, ensiling Napier grass with poultry excreta, rice straw and molasses will increase crude protein and other nutritive value of the diet. Considering the above evidence, wastelage was prepared by different level of poultry droppings and Napier grass to evaluate its quality, better for suitable as ruminant feed.

\section{Materials and Method}

\section{Experimental site}

The experiment was conducted in two phases: The first phase was the preparation of wastelage and second phase was laboratory analysis of wastelage. Preparation of wastelage and related activities were carried out in the Goat and Sheep farm, Department of Animal Science, Bangladesh Agricultural University, Mymensingh during the period from $6^{\text {th }}$ March to $19^{\text {th }}$ May, 2018. The laboratory analysis of wastelage was completed in the Animal Science and Animal Nutrition laboratory in the department of Animal Science and Animal Nutrition, respectively, Bangladesh Agricultural University, Mymensingh.

\section{Collection of experimental materials}

Cage layer poultry dropping (PD) was collected from Poultry Farm, Bangladesh Agricultural University (BAU), and Napier grass and rice straw were collected from Goat and Sheep farm, Department of Animal Science, Bangladesh Agricultural University, Mymensingh. Molasses and air tight plastic container (30L size) were purchased from local market.

\section{Preparation of wastelage}

Napier grass was collected just after harvesting. After collecting grass and rice straw were chopped about 3-4 cm long. Then wastelage was prepared by mixing chopped grass and rice straw with fresh poultry litter and molasses. There were 4 treatments group. The experimental treatments were:

To $=0 \%$ poultry dropping $+75 \%$ Napier grass + $5 \%$ molasses $+20 \%$ rice straw,

$\mathbf{T}_{\mathbf{1}}=15 \%$ poultry dropping $+60 \%$ Napier grass + $5 \%$ molasses $+20 \%$ rice straw,

$\mathbf{T}_{\mathbf{2}}=30 \%$ poultry dropping $+45 \%$ Napier grass + $5 \%$ molasses $+20 \%$ rice straw,

$\mathbf{T}_{\mathbf{3}}=45 \%$ poultry dropping $+30 \%$ Napier grass + $5 \%$ molasses $+20 \%$ rice straw.

These prepared mixtures were placed into airtight plastic containers. Finally plastic containers were kept in a room for 75 days for successful ensiling. These ensiled products are known as wastelage. Wastelage samples were analyzed at $0,30,45,60$ and 75 days.

\section{Physical and organoleptic test of wastelage}

Texture (hardness), color and smell of samples were recorded. The results of these parameters were summarized according to the opinions of 
farms attendants, laboratory students of department of Animal science, Bangladesh agricultural University. Acceptability of wastelages by cattle were also tested to observe the palatability level.

\section{Chemical analyses}

$\mathrm{pH}$ was determined by using digital $\mathrm{pH}$ meter (ino Lab, Germany) after keeping 2 gram sample with $50 \mathrm{ml}$ distilled water. Dry matter was determined by oven drying method at $65^{\circ} \mathrm{C}$ for about 48 hours. Crude protein (CP) was measured by Kjeldal method while other proximate components crude fiber (CF), ether extract (EE), nitrogen free extract (NFE) were measured according to the method described by AOAC (2004). In vitro organic matter digestibility (IVOMD) and metabolizable energy (ME) content of wastelage were done following the method described by Menke et al. (1979).

\section{Statistical analysis}

The experiment was laid out in a $4 \times 5$ Factorial Design with 3 replicate in each treatment. Data were statistically analyzed using SAS Statistical Discovery Software, NC, USA and differences among the treatment means were determined by Duncan's Multiple Range Test (DMRT).

\section{Results}

\section{Physical properties and $\mathrm{pH}$ of ensilage}

The physical properties of ensilage of different treatments $\left(T_{0}, T_{1}, T_{2}\right.$ and $\left.T_{3}\right)$ at different ensiling time $(0,30,45,60$ and 75 days) were shown in Table 1. After 75 days of ensiling period, the color of different treatments $\left(T_{0}, T_{1}, T_{2}\right.$ and $\left.T_{3}\right)$ were brown, light brown, dark brown and chocolate. The color of ensilage became deeper with the increasing level of Poultry droppings. All the treatments had good color. Among all the treatments, $T_{2}$ and $T_{3}$ had good smell at 75 days of ensiling and $T_{1}$ had bad smell. Controlled treated ensilage remained hard but $T_{1}, T_{2}$ and $T_{3}$ became soft after 75 days of ensiling. Fungus propagation was not observed in Poultry droppings treated wastelage but some seen in controlled treatment.

The $\mathrm{pH}$ is shown in Figure 1. Significant differences $(P<0.05)$ were observed among the treatments. After ensiling, the highest $\mathrm{pH}$ value was observed by treatment $T_{0}$ followed by $T_{1}, T_{2}$ and $\mathrm{T}_{3}$. It was observed that $\mathrm{pH}$ value decreased with the increase level of Poultry droppings. In the present studies, $\mathrm{pH}$ values lower than 5 were attained in all ensilage. Irrespective of treatments, the $\mathrm{pH}$ values of ensilage of different ensiling period $(0,30,45,60$ and 75 days) are shown in Figure 1. The $\mathrm{pH}$ value was decreased $(P<0.05)$ from 0 to 75 days.

\section{Chemical composition of Napier grass and poultry dropping wastelage}

\section{Dry matter}

The dry matter content of ensilage of different treatments and different ensiling time is shown in Table 2. It was observed that Dry Matter (DM) content $(\mathrm{g} / 100 \mathrm{~g})$ of ensilage differ $(P<0.05)$. The highest $D M$ was obtained in $T_{3}$ followed by $T_{0}, T_{1}$ and $T_{2}$. The lowest DM was obtained by the control treatment $T_{0}$. The $D M$ at different treatments $T_{0}, T_{1}, T_{2}$ and $T_{3}$ were found 26.69, $29.72,29.43$ and $33.58 \%$ respectively. Therefore DM content increased as the level of PD increased from 0 to $45 \%$ of the total dry matter. The dry matter at ensiling time of $0,30,45,60$ and 75 days was found $41.90,28.62,27.09,26.27$ and $25.38 \%$ respectively. It was observed that DM content was decreased $(P<0.05)$ from 41.90 to $25.38 \%$ with the increase of duration ensiling from 0 to 75 days.

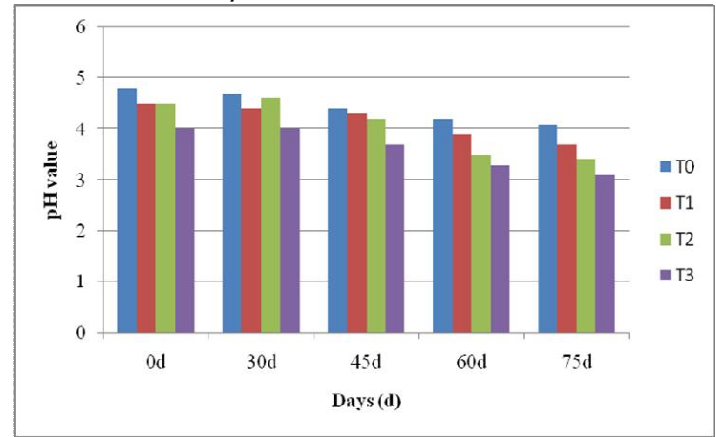

Figure 1. $\mathrm{pH}$ values of wastelage of different treatments and at different ensiling time

\section{Crude protein}

The Crude Protein (CP) content of different treatments $\left(T_{0}, T_{1}, T_{2}\right.$ and $\left.T_{3}\right)$ of ensilage was $14.27,16.74,17.75$ and $19.16 \%$, respectively which is shown in Table 3. The highest (19.16\%) $\mathrm{CP}$ content was found in T3 and the lowest $(14.27 \%)$ CP content was found in T0. The CP content differ with the addition of poultry droppings $(P<0.05)$. The CP content of wastelage in different ensiling period $(0,30,45,60$, and 75 days) were 9.24, 16.39, 17.49, 19.00 and $22.77 \%$ respectively. It was observed that CP content was increased from 9.24 to $22.77 \%$ with the ensiling time from 0 to 75 days, which was statistically significant $(P<0.05)$. 
Panna et al. (2019) Bang. J. Anim. Sci. 48 (1):48-56

Table 1. Effect of different treatments on physical qualities of wastelage.

\begin{tabular}{|c|c|c|c|c|c|}
\hline \multirow{2}{*}{ Characteristics } & \multirow{2}{*}{ Observation } & \multicolumn{4}{|c|}{ Treatments } \\
\hline & & $\mathbf{T}_{0}$ & $\mathbf{T}_{1}$ & $\mathbf{T}_{2}$ & $\mathbf{T}_{3}$ \\
\hline \multirow{5}{*}{ Color } & 0 Day & Brown color & Brown color & Light Brown & Light Brown \\
\hline & 30 Days & Light Brown & Light Brown & Brown & Brown \\
\hline & 45 Days & Light Brown & Brown & Brown & Brown \\
\hline & 60 Days & Brown & Brown & Dark Brown & Dark Brown \\
\hline & 75 Days & Chocolate & Brown & Dark Brown & Dark Brown \\
\hline \multirow{5}{*}{ Smell } & 0 Day & Straw & Straw & Pleasant smell & Pleasant smell \\
\hline & 30 Days & Straw & Straw & Pleasant smell & Pleasant smell \\
\hline & 45 Days & straw & Moderate Good & Good odor & Acceptable smell \\
\hline & 60 Days & Straw & Good odor & Acceptable smell & Pleasant smell \\
\hline & 75 Days & Straw & Bad smell & Pleasant smell & Good smell \\
\hline \multirow{5}{*}{ Softness } & 0 Day & Hard & Hard & Hard & Hard \\
\hline & 30 Days & Hard & Hard & Hard & Hard \\
\hline & 45 Days & Hard & Moderate soft & Moderate Soft & Soft \\
\hline & 60 Days & Hard & Soft & Soft & Soft \\
\hline & 75 Days & Hard & Soft & Soft & Soft \\
\hline \multirow{5}{*}{ Fungus } & 0 Day & Absent & Absent & Absent & Absent \\
\hline & 30 Days & Absent & Absent & Absent & Absent \\
\hline & 45 Days & Absent & Absent & Absent & Absent \\
\hline & 60 Days & Present & Absent & Absent & Absent \\
\hline & 75 Days & Present & Absent & Absent & Absent \\
\hline
\end{tabular}

\section{Crude fiber}

The Crude Fiber (CF) content of ensilage of different treatments and different ensiling time is shown in Table 4. The CF content of different treatments $\left(T_{0}, T_{1}, T_{2}\right.$ and $\left.T_{3}\right)$ of ensilage was $22.14,21.67,21.77$ and $20.78 \%$, respectively. In the present experiment the value of CF was significantly higher $(P<0.05)$ in controlled $\mathrm{T}_{0}$

(22.14\%) than treated $\left(T_{1}, T_{2}\right.$ and $\left.T_{3}\right)$ Napier grass. The CF content was decreased significantly $(P<0.05)$ from 22.14 to $20.78 \%$ with the addition of PD ( 0 to $45 \%$ ) but again increased in $\mathrm{T}_{2}$ than $\mathrm{T}_{1}$ which was not statistically significant $(P>0.05)$. The CF content of wastelage in different ensiling period $(0,30,45,60$ and 75 days) was 23.31, $22.46,21.22,19.46$ and $16.25 \%$, respectively. It was observed that CF was decreased with ensiling period where 0 day was differ from 75 days $(P<0.05)$.

\section{Ether extract}

The Ether Extract (EE) content of ensilage of different treatments and different ensiling time is shown in Table 5.The EE content of different treatments $\left(T_{0}, T_{1}, T_{2}\right.$ and $\left.T_{3}\right)$ of ensilage was $4.69,3.79,3.59$ and $2.89 \%$, respectively. It was observed that EE was decreased with the addition of poultry droppings but the differences between
$\mathrm{T}_{1}$ and $\mathrm{T}_{2}$ were not significant $(P>0.05)$. The highest EE was obtained by T0 treatment followed by $T_{1}, T_{2}$ and $T_{3}$. The EE content of ensilage in different ensiling time $(0,30,45,60$ and 75 days $)$ was $4.53,4.07,3.80,3.48$ and $2.81 \%$, respectively. It was observed that $\mathrm{EE}$ was decreased $(P<0.05)$ from 4.53 to $2.81 \%$ with the time of 0 to 75 days.

\section{Ash}

The ash content of ensilage of different treatments and different ensiling time is shown in Table 6. The ash content of different treatments $\left(T_{0}, T_{1}, T_{2}\right.$ and $\left.T_{3}\right)$ of ensilage was $4.25,4.72$, 4.91 and $5.32 \%$, respectively. There was no differences among $T_{0}, T_{1}$ and $T_{2}$. The ash content was increased significantly $(P<0.05)$ with the increase of poultry litter percentage. The highest $(5.32 \%)$ ash content was found in $\mathrm{T}_{3}$ and lowest $(4.32 \%)$ ash content found in $T_{0}$. From Table 6, it is revealed that $T_{3}$ gave the highest ash content, followed by $T_{0}, T_{1}$ and $T_{2}$ The ash content of ensilage in different ensiling time $(0,30,45,60$ and 75 days) was $5.07,4.80,4.62,4.61$ and $4.53 \%$, respectively. It was observed that the ash content was decreased from 5.07 to $4.53 \%$ with the increase of ensiling period from 0 to 75 days but not statistically significant among the treatments. 
Napier grass and poultry dropping wastelage

Table 2. Effect of treatments and ensiling time on dry matter of ensilage

\begin{tabular}{ccccccc}
\hline & \multicolumn{7}{c}{ Treatments } \\
\cline { 2 - 7 } Ensiling (Days) & $\mathbf{T}_{\mathbf{0}}$ & $\mathbf{T}_{\mathbf{1}}$ & $\mathbf{T}_{\mathbf{2}}$ & $\mathbf{T}_{\mathbf{3}}$ & Mean & SEM \\
\hline 0 & 39.21 & 40.40 & 43.62 & 44.40 & $41.90^{\mathrm{a}}$ & 0.56 \\
30 & 24.60 & 30.61 & 25.70 & 33.70 & $28.62^{\mathrm{b}}$ & 0.60 \\
45 & 23.50 & 27.52 & 25.71 & 31.71 & $27.09^{\mathrm{C}}$ & 0.50 \\
60 & 23.40 & 25.70 & 26.50 & 29.50 & $26.27^{\mathrm{d}}$ & 0.61 \\
75 & 22.80 & 24.50 & 25.70 & 28.60 & $25.38^{\mathrm{e}}$ & 0.63 \\
Mean & $26.69^{\mathrm{a}}$ & $29.72^{\mathrm{b}}$ & $29.43^{\mathrm{C}}$ & $33.58 \mathrm{~d}$ & & \\
SEM & 0.57 & 0.52 & 0.58 & 0.60 & &
\end{tabular}

Means with different superscripts within row and column are significantly different $(P<0.05)$

Table 3. Effect of treatments and ensiling time on crude protein of ensilage

\begin{tabular}{ccccccc}
\hline \multirow{2}{*}{ Ensiling (Days) } & \multicolumn{7}{c}{ Treatments } \\
\cline { 2 - 7 } & $\mathbf{T}_{0}$ & $\mathbf{T}_{1}$ & $\mathbf{T}_{2}$ & $\mathbf{T}_{3}$ & Mean & SEM \\
\hline 0 & 6.27 & 8.50 & 9.45 & 12.74 & $9.24^{\mathrm{e}}$ & 0.57 \\
30 & 11.49 & 17.50 & 17.87 & 18.74 & $16.39^{\mathrm{d}}$ & 0.53 \\
45 & 14.57 & 17.91 & 18.48 & 19.03 & $17.49^{\mathrm{C}}$ & 0.56 \\
60 & 17.77 & 17.99 & 19.55 & 20.73 & $19.00^{\mathrm{b}}$ & 0.59 \\
75 & 21.27 & 21.85 & 23.41 & 24.59 & $22.77^{\mathrm{a}}$ & 0.64 \\
Mean & $14.27^{\mathrm{d}}$ & $16.74^{\mathrm{C}}$ & $17.75^{\mathrm{b}}$ & $19.16^{\mathrm{a}}$ & & \\
SEM & 0.57 & 0.54 & 0.56 & 0.63 & & \\
\hline
\end{tabular}

Means with different superscripts within row and column are significantly different $(P<0.05)$

Table 4. Effect of treatments and ensiling time on crude fiber of ensilage

\begin{tabular}{ccccccc}
\hline \multirow{2}{*}{ Ensiling (Days) } & \multicolumn{7}{c}{ Treatments } \\
\cline { 2 - 7 } & $\mathbf{T}_{0}$ & $\mathbf{T}_{1}$ & $\mathbf{T}_{2}$ & $\mathbf{T}_{3}$ & Mean & SEM \\
\hline 0 & 25.49 & 24.29 & 22.14 & 21.34 & $23.31^{\mathrm{a}}$ & 0.61 \\
30 & 24.17 & 23.22 & 21.71 & 20.74 & $22.46^{\mathrm{ab}}$ & 0.77 \\
45 & 22.21 & 21.05 & 20.57 & 21.06 & $21.22^{\mathrm{ab}}$ & 0.60 \\
60 & 19.79 & 19.88 & 21.37 & 20.83 & $19.46^{\mathrm{ab}}$ & 0.59 \\
75 & 19.10 & 18.91 & 17.09 & 19.91 & $16.25^{\mathrm{b}}$ & 0.57 \\
Mean & $22.14^{\mathrm{b}}$ & $21.67^{\mathrm{a}}$ & $21.77^{\mathrm{a}}$ & $20.78^{\mathrm{a}}$ & & \\
SEM & 0.60 & 0.71 & 0.60 & 0.61 & & \\
\hline
\end{tabular}

Means with different superscripts within row and column are significantly different $(P<0.05)$

\section{Nutritive values of ensilage}

The organic matter digestibility (OMD) of ensilage of different treatments and different ensiling time is shown in figure 2 . The OMD content of different treatments $\left(T_{0}, T_{1}, T_{2}\right.$ and $\left.T_{3}\right)$ of ensilage was 54.08, 55.75, 57.03 and $61.09 \%$, respectively. It showed that the highest in vitro OMD was observed in T3 and the lowest was in T0. The in vitro organic matter digestibility (OMD) 
in different treatments differed $(P<0.05)$ due to different levels of PD.

\section{Metabolizable Energy}

The values for metabolizable energy (ME) content $(\mathrm{MJ} / \mathrm{kg} \mathrm{DM})$ of ensilage were differed significantly among the treatment is shown on figure $\mathbf{3}$. The
ME content of different treatments $\left(T_{0}, T_{1}, T_{2}\right.$ and $T_{3}$ ) of ensilage was $4.88,5.72,5.94$ and 6.98 respectively. The highest ME (6.98) was observed in $T_{3}$ which was higher than that of $T_{0}, T_{1}, T_{2}$ treatment. The lowest ME (4.88) was observed in control treatment $\left(T_{0}\right)$.

Table 5. Effect of treatments and ensiling time on ether extract of ensilage

\begin{tabular}{ccccccc}
\hline \multirow{2}{*}{ Ensiling (Days) } & \multicolumn{7}{c}{ Treatments } \\
\cline { 2 - 7 } & $\mathbf{T}_{0}$ & $\mathbf{T}_{1}$ & $\mathbf{T}_{2}$ & $\mathbf{T}_{3}$ & Mean & SEM \\
\hline 0 & 4.91 & 4.81 & 4.71 & 3.80 & $4.53^{\mathrm{a}}$ & 0.58 \\
30 & 5.64 & 3.99 & 3.81 & 2.88 & $4.07^{\mathrm{ab}}$ & 0.59 \\
45 & 3.81 & 4.21 & 4.11 & 3.11 & $3.80^{\mathrm{ab}}$ & 0.54 \\
60 & 4.91 & 3.41 & 3.21 & 2.41 & $3.48^{\mathrm{bc}}$ & 0.56 \\
75 & 4.21 & 2.56 & 2.16 & 2.36 & $2.81^{\mathrm{c}}$ & 0.55 \\
Mean & $4.69^{\mathrm{a}}$ & $3.79^{\mathrm{b}}$ & $3.59^{\mathrm{bc}}$ & $2.89^{\mathrm{c}}$ & & \\
SEM & 0.58 & 0.52 & 0.53 & 0.54 & &
\end{tabular}

Means with different superscripts within row and column are significantly different $(P<0.05)$

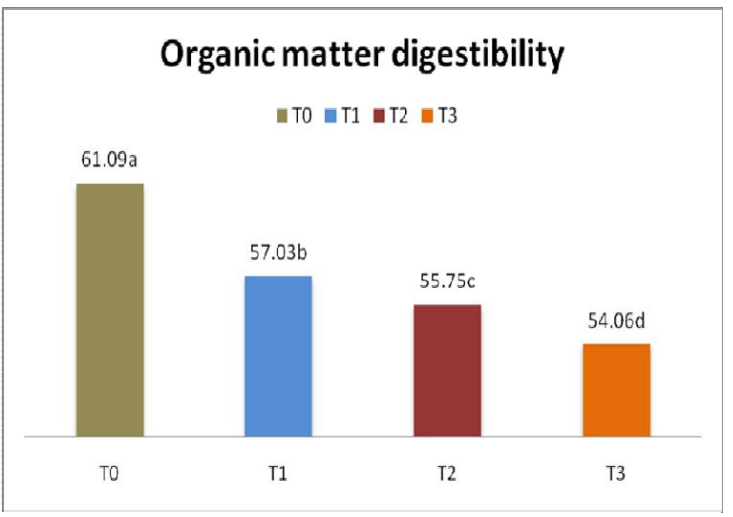

Figure 2. In vitro organic matter digestibility $(\%)$ of ensilage at different levels of poultry

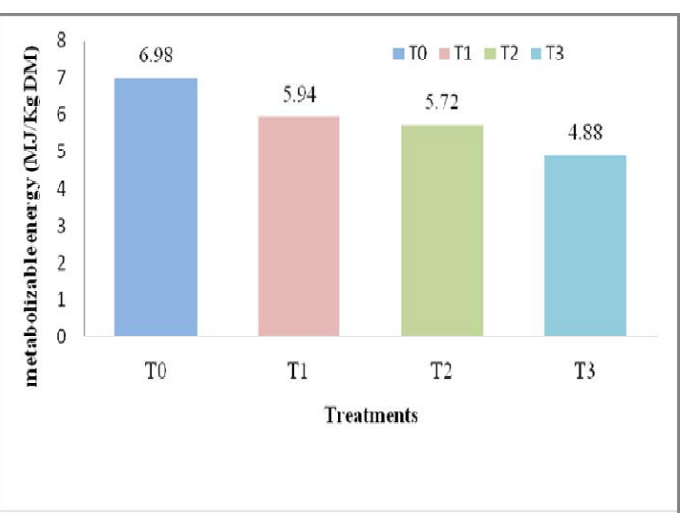

Figure 3. Metabolizable Energy (MJ/kg DM) of ensilage at different level of poultry litter.

Table 6. Effect of treatments and ensiling time on ash of ensilage

\begin{tabular}{ccccccc}
\hline \multirow{2}{*}{ Ensiling (Days) } & \multicolumn{7}{c}{ Treatments } \\
\cline { 2 - 7 } & T0 & T1 & T2 & T3 & Mean & SEM \\
\hline 0 & 4.27 & 4.74 & 5.30 & 5.98 & 5.07 & 0.63 \\
30 & 3.63 & 4.59 & 4.38 & 5.51 & 4.80 & 0.56 \\
45 & 4.12 & 4.98 & 4.35 & 5.22 & 4.62 & 0.58 \\
60 & 4.57 & 4.35 & 4.57 & 4.99 & 4.61 & 0.54 \\
75 & 4.72 & 4.94 & 5.41 & 4.12 & 4.53 & 0.59 \\
Mean & $4.25^{\mathrm{b}}$ & $4.72^{\mathrm{b}}$ & $4.91^{\mathrm{ab}}$ & $5.32^{\mathrm{a}}$ & & \\
SEM & 0.46 & 0.59 & 0.62 & 0.52 & & \\
\hline
\end{tabular}

Means with different superscripts within row and column are significantly different $(P<0.05)$.

\section{Discussion}

Different experiments of wastelage had shown the physical properties of the final products. A pleasing aroma and good color was obtained when $40 \%$ poultry droppings were ensiled with maize stover (Jamee 2014). This result was almost similar with our findings. Properly ensiled silage had good color and smell (Schroeder 2013). Ensilage that ensiled with cage-layer waste 
(nitrogen source) results gold brown color, pleasant aroma and no mould growth (Kayongo et al., 1986).This indicate that ensiling grass with poultry dropping will not have any bad odor.

The lower $\mathrm{pH}$ of ensilage indicates good fermentation quality which was due to presence of higher water soluble carbohydrates in fodder that enhanced lactic acid production (Yunus et al., 2000). Roothaert et al. (1992) indicated that ensiled materials should reach a pH of less than 5 in order to destroy Salmonella and other pathogens. In the present studies, $\mathrm{pH}$ values lower than 5 were attained in all ensilage. Lower $\mathrm{pH}$ levels helps for faster fermentation and facilitate preservation which retain more nutrients in the silage (Schroeder 2013). The present study of wastelage indicated that they are highly fermented and lactic acid production is higher which will help to conserve more nutrients in the ensilage. Dry matter content of wastelage differs with the different amount of poultry dropping. In contrast to the present findings, Fontenot and Webb (1975) reported that the DM level was increased by increasing the level of poultry droppings. Ensiling with poultry litter increased the dry matter (DM) composition of silage which supported by the report of Al- Rokayan et al. (1988) when Broiler litter was ensiled with sorghum forage in the proportions $0: 100,25: 75$, 35: 65 and 45:55. Similar result was also reported by Flachowsky and Hennig (1990). DM was decreased from 22.58 to $20.83 \%$ (Otieno et al., 1986) and from 29.1 to $26.5 \%$ (Hiep and Man 2003) in ensiled maize stover. It was observed that DM content was decreased with the ensiling time from 31.76 to $27.37 \%$ with the increase of duration from 0 to 90 days (Sarker et al., 2018). Losses of DM may come from run off, oxidation and loss of volatile organic compounds (Kung 2010).

The change of CP in wastelage of our study had been compared with other studies. Similar results had been reported by Daniels et al. (1983) reported who ensiled maize with broiler litter for 6 weeks and found that CP was increased with increased proportion of poultry litter. The crude protein of sorghum forages ensiled with broiler litter increased with increased proportion of poultry litter (Al-Rokayan et al., 1988; Flachowsky and Henning, 1990). Ngele et al. (2006) ensiled rice straw with poultry litter at different rations and recorded highest crude protein in ratio 50:50. Ensiling time increase the $\mathrm{CP}$ content when maize ensiled with nitrogen source (caged layer waste) (Kayongo et al., 1986). Similar results have been reported by Daniels et al. (1983) and Hadjipanayiotou (1984).
The result supported by Mohanta (2005), who stated that, in different days (7, 15 and 21 days) of ensiling $\mathrm{CP}$ content were different and were highest in 21 days.

The result of this experiment was related by Baba et al. (2010), who reported that when Kyasuwa hay (Pennisetum pedicellatum) ensiled with poultry litter at treatment $80: 20$ and 50:50 the CF was decreased from $20.46 \%$ to $15.95 \%$. Rasool et al. (1998) observed a decline in NDF, hemicelluloses and cellulose (Fiber component) in sudax fodder ensiled with broiler litter and molasses. Magar and Fontenot (1988) and Rasoolo et al. (1996) also observed a similar trend in rice straw ensiled with poultry litter. CF decreased with the level of caged layer waste (nitrogenous source) in the maize stover (Kayongo et al., 1986). The reason of CF decrease may be due to the lower CF content of CLE and also decomposition of silage materials. CF was reduced with increasing the ensiling time, when ensiled with caged layer waste (nitrogenous source) (Kayongo et al., 1986). Baba et al. (2010) reported that when Kyasuwa hay (Pennisetum pedicellatum) ensiled with poultry litter, EE declined with increased proportion of poultry litter. Variation of the present observation may due to the variation of poultry litter and ensiling materials.

This result of ash of our study was supported by Al-Rokayan et al. (1988) and Flachowsky and Hennig (1990), who observed a linear increase in ash with increased proportion of broiler litter. In the present study, the ash content was decreased with the ensiling period might be due to utilization of ash for the microbial growth during the ensiling period. This result is not supported by Al-Rokayan et al. (1988) and Flachowsky and Hennig (1990) who observed a linear decrease in ash with increased proportion of broiler litter. Jalc et al. (2009) reported that bacterial inoculation during ensiling did not affect ash content of grass and corn silages. Kim et al. (2014), indicated that the ash content of silage increase up to 28 days of ensiling. This result of our study for organic matter digestibility was partially supported by Reddy and Reddy (1980), who reported that in vitro organic matter digestibility of rice straw increase when ensiled with rumen digesta and animal excreta. Saylor and Long (1972) reported that in vitro organic matter digestibility of ensiled crop residue and poultry manure positively increased with the level of poultry manure. Predicted OMD was increased in maize stover ensiled with caged layer waste (Kayongo et al., 1986). 
The present study showed that ensiling of napier grass increase ME value of wastelage. Similar trend was also reported by Ali et al. (1994) who indicated that in vitro DM digestibility and ME were increased in treated stover compared with untreated stover after ensiling. Bostami et al. (2009) also reported that ME content was increased in treated ensiled maize stover than untreated ensiled maize stover. Cone et al. (2008) reported that ensiling period has no $(P>0.05)$ effect on ME content of silage.

\section{Conclusion}

The results of this study revealed that wastelage prepared from $45 \%$ poultry dropping and $30 \%$ Napier grass had higher nutritional and preservation qualities than other treatments. This wastelage can be cheap, available and good source of ruminant feed which can be provided year round specially during scarcity period. Besides it will associate to reduce the environmental pollution by converting this waste and by products into valuable ruminants feed.

\section{References}

Al-Rokayan SA, Z Naseer and SM Chaudhry (1988). Nutritional quality and digestibility of sorghumbroiler litter silages. Animal Feed Science Technology. 75:65-73.

Ali I, JP Fontenot and VG Allen (1994). Fermentation characteristics, chemical changes and in vitro dry matter digestibility of corn stover treated with different sources of nitrogen (small silo study). Pakistan Veterinary Journal 14(4):185193.

AOAC (2004). Association of the Official Agricultural Chemists, Official methods of analysis. Washington, DC, pp. 1-34.

Baba M, T Uba and AR Halim (2010). Nutritive value of Kyasuwa hay (Pennisetum pedicellatum) ensiled with poultry litter at varying proportions. Research Journal of Animal Science 4:17-120.

Bangladesh Economic Survey (2015). Finance Division, Ministry of Finance and planning, Government of the People's Republic of Bangladesh.

Bostami AB, RI Khan, MM Rahman, A Mondal, NR Sarker and MR Hasan (2009). Study on the effect of ensiling with or without urea on physical quality, chemical composition and in vitro digestibility of maize stover. Journal of Agroforestry Environment 3(1):167-171.

Cone JW, AH Van Gelder, HA Van Schooten and JA Groten (2008). Effects of chop length and ensiling period of forage maize on in vitro rumen fermentation characteristics. NJASWageningen Journal of Life Sciences 55(2):155166.

Daniels LB, MJ Smith, OT Stallcup and JM Rakes (1983). Nutritive value of ensiled broiler litter for cattle. Animal Feed Science and Technology 8(1):19-24.

DLS (Department of Livestock Services) (2018). Livestock economy at a glance, Ministry of Livestock and Fisheries, Dhaka, Bangladesh.

DLS 2016: Annual report on livestock (2016). Division of Livestock Statistics, Ministry of Fisheries and Livestock, Farmgate, Dhaka, Bangladesh.

Flachowsky G and A Henning (1990). Composition and digestibility of untreated and chemically treated animal excreta for ruminants. A review: Biological wastes 31(1):17-36.

Fontenot JP and KE Webb (1975). Health aspects of recycling animal waste by feeding. Journal of Animal Science 40:1267.

GOB (Govt. of Bangladesh) (2010). Report of the task forces on Bangladesh development strategies of the 2010's. Univ. press Ltd, Dhaka, Bangladesh. P 2-4.

Hadjipanayiotou M (1984). The use of Poultry Litter as ruminant feed in Cyprus. World Animal Review 49:32-38.

Haque QM, SM Amanullah and MM Islam (2007). Introduction of forage crops with the existing cropping system of different agro-ecological zones of Bangladesh and its impact analysis. Progress Report, Animal Production Division, BLRI (2005-06).

Hiep NV and NV Man (2003). Dairy Cattle feed from stover derived from mature and immature maize crops in small holder crop-livestock production system in Vietnam. University of Agriculture and Forestry, Thu Duc, Ho Chi Minh city, Vietnam. mammy@hcm.vnn.vn.

Jalc DA, MP Laukova, Z Simonova, M Varadyova and $P$ Homolka (2009). The use of bacterial inoculants of grass silage; their effects on nutrient composition and fermentation parameters in grass silage. Czech Journal of Animal Science 54(2):84-91.

Jamee DK (2014). Use of poultry droppings and maize stover to prepare wastelage for environment friendly livestock agriculture. M. S. Thesis, Department of Animal Science. Bangladesh Agricultural University, Mymensingh.

Kayongo SB, MM Wanyoike, PN Nyagah, PN Maitho and PN Mbugua (1986). Caged layer waste as nitrogen source in crop-residue utilization. Department of Animal Production, Faculty of Veterinary Medicine, University of Nairobi, Nairobi, Kenya. Net Search.

Kim YI, YK Oh, KK Park, WS Kwak (2014). Ensiling Characteristics and the In situ Nutrient Degradability of a By-product Feed-based Silage. Asian Australian Journal of Animal Science 27(2):201-208.

Kung JL (2010). Understanding the biology of silage preservation to maximize quality and protect the environment. In Proceedings, 2010 California Alfalfa \& Forage Symposium and Corn/Cereal Silage Conference (pp. 12). 
Magar SM and JP Fontenot (1988). Nutritional value of ensiled deep pit caged layer waste-corn forage mixtures. Virginia Technical Livestock Research Report No 7, Blacksburg, pp: I 33136.

Menke KH, L Raab, A Salewski, H Steingass, D Fritz and W Schneider (1979). The estimation of the digestibility and metabolizable energy content of ruminant feeding stuffs from the gas production when they are incubated with rumen liquor in vitro. Journal of Agricultural Science 93:217222.

Mohanta NG (2005). Improvement of the nutritive value of rice straw through treatment with urea, urease sources and plant leaves. M.S. Thesis, Department of Animal Nutrition. Bangladesh Agricultural University, Mymensingh.

Ngele MA, TA Adegbola and SE Bogoro (2006). Nutritive value of rice straw treated with poultry litter. In Proceedings of the 31st Annual Conference of Nigerian Society for Animal Production, March (pp.12-15).

Otieno K, JFM Onim and MN Mathuva (1986). A gunny bag ensiling technique for small scale farmers in Western Kenya. Ministry of Livestock Department /SR-CRSP, Maseno, Kenya.

Premier M (2006). Farm use of molasses. Molasses as a silage preservative. Benefits of molasses.www.premiermolasses.ie

Rasool S, MA Sial, H Ahsan-ul and A Jamil (1998). Chemical changes during ensiling of sudaxrodder with broiler litter. Animal Feed Science and Technology 72:347-354.
Rasool S, SH Hanjra and A Jamil (1996). Effect of ensiling sudax fodder with broiler litter and Candida yeast on the changes in different fiber fractions. Animal feed Science and Technology 57(4):325-333.

Reddy MR and KVS Reddy (1980). A short note on the proximate composition of rumen digesta from bovine and ovine species and its utilization as a component of livestock feed. Indian Veterinary Journal 57(5):429-431.

Roothaert RL and RW Matthewman (1992). Poultry wastes as foods for ruminants and associated aspects of animal welfare - Review. American Journal of Animal Science 5(4):593-600.

Sarker LR, MRI Khan and MM Rahman (2018). Ensiling of Wet Rice Straw using Biogas Slurry and Molasses in Monsoon of Bangladesh. Journal of Animal Sciences and Livestock Production 2:1-2.

Saylor WW and TA Long (1972). Laboratory evaluation of ensiled poultry waste. Journal of Animal Science 39:139.

Schroeder JW (2013). Silage fermentation and preservation. NDSU Extension service. AS1254.

Strickler RH (1977). Deep stacking broiler litter as a means of storage for use in feeding beef cows In: alternate nitrogen sources for ruminants, pp.56-57. Conference, 9-11 November 1977, Atlanta, Georgia, USA.

Yunus $M, N$ Ohba, $M$ Shimojo, $M$ Furuse and $Y$ Masuda (2000). Effects of adding urea and molasses on Napier grass silage quality. Asian Australian Journal of Animal Science 13(11):1542-1547. 